\title{
Analysis of the Distribution of Heavy Metals in Well Water
}

\author{
Fatma Suryani Harahap ${ }^{1}$, Nova Irawati Simatupang ${ }^{2 *}$ \\ ${ }^{I}$ Department of Chemical Education, Universitas Muhammadiyah Tapanuli Selatan, Indonesia \\ ${ }^{2}$ Department of Chemical Education, Universitas Kristen Indonesia \\ Corresponding authors. Ee-mail: nova@uki.ac.id
}

\begin{abstract}
Well water for residents around the TPA is the main source of water for the community because all water needs are met from well water, whether for drinking, cooking, bathing, washing, feeding livestock and other needs. Any change in water quality due to the influence of leachate from the TPA will affect well water users, especially for their health. People in this environment are very at risk of health problems, especially due to soil pollution from leachate from the landfill. This research aims to determine the distribution of lead $(\mathrm{Pb})$, mercury $(\mathrm{Hg})$ and copper $(\mathrm{Cu})$ metal content in community wells around the Batu Bola landfill. This research method is to apply exploratory descriptive method. The results of the measurement of metal content were then analyzed by comparing the measurement result data with quality stones issued by Permenkes No. 492 of 2010 concerning Requirements for Drinking Water Quality and Government Regulation Number 82 of 2001 concerning Management of Water Quality and Control of Water Pollution in Class I. The concentration of $\mathrm{Hg}$ in well 1 and well 2 is $<0.0004 \mathrm{mg} / \mathrm{L}$. While the threshold set by the government is $0.001 \mathrm{mg} / \mathrm{L}$ and $0.002 \mathrm{mg} / \mathrm{L}$. The concentration of lead metal $(\mathrm{Pb})$ in well 1 and well 2 is $<0.003 \mathrm{mg} / \mathrm{L}$, while the quality standards set by the government are $0.01 \mathrm{mg} / \mathrm{L}$ and $0.03 \mathrm{mg} / \mathrm{L}$. The measurement of the concentration of copper metal $(\mathrm{Cu})$ in well 1 and well 2 is $<0.006 \mathrm{mg} / \mathrm{L}$, while the quality standards set are $2 \mathrm{mg} / \mathrm{L}$ and $0.02 \mathrm{mg} / \mathrm{L}$. The metal content test results showed that all the wells were still below the established quality standards.
\end{abstract}

Keywords: $\mathrm{AAS}, \mathrm{Cu}, \mathrm{Hg}, \mathrm{Pb}$, Well Water

\section{INTRODUCTION}

The requirements for the quality of drinking water must comply with the provisions contained in the Decree of the Minister of Health of the Republic of Indonesia No.492/Menkes /per/IV/2010, where each component contained in drinking water must comply with the stipulated regulations / requirements. Drinking water as an essential need also has the potential to transmit diseases, poisoning and so on (Bali 2012). According to the Ministry of Health, drinking water must meet health requirements that have been determined by the maximum limit. Drinking water parameters are divided into several parts, including the following: physical parameters include odor, amount of dissolved solids, turbidity, taste, temperature and color. (Wardi, E.S, Arel, A dan Yongki 2018). Chemical parameters include mercury, barium, iron, cadmium, chloride, chromium, manganese and others. Biological parameters include coliform, pathogenic bacteria and viruses. Radioactivity parameters, including alpha and beta rays. (Nasution, H.I dan Silaban 2017).

To meet the community's need for clean water for drinking, water treatment is carried out from water sources, one of which is well water. Well water can be classified into shallow groundwater $(0-40 \mathrm{~m})$ and deep ground water (> $40 \mathrm{~m}$ ). Generally, people use well water that comes from shallow groundwater. The decline in groundwater quality is indicated by the detection of several heavy metal pollutants such as chromium $(\mathrm{Cr})$, copper $(\mathrm{Cu})$, mercury $(\mathrm{Hg})$, lead $(\mathrm{Pb})$ and other metals from industrial waste, landfills (TPA), use of fertilizers. excessive and domestic waste is categorized as a source of direct contaminants, while the source of indirect contaminants is the seepage of surface water that enters groundwater or the atmosphere in the form of rain. (Anilkumar, A., D. Sukamaran 2015).

Waste management in Indonesia is a real problem in line with the increasing population growth rate which results in an increase in the amount of waste produced. Therefore, this problem means that waste must be managed properly. An example of a landfill in Indonesia is the Batu Bola landfill in Pangsidimpuan City, which still uses the Open Dumping method. Around this TPA there are residential areas less than 200 meters away, and there is also the Batang Ayumi river. (Harahap 2018) have 
conducted research on the Batang Ayumi river water which is flowed by leachate from the Batu Bola landfill, this research proves that the river water has been contaminated with heavy metals $\mathrm{Cu}$.

Heavy metals are divided into two types, namely, essential heavy metals which are metals in certain amounts that are needed by organisms. However, these metals can cause toxic effects if in excessive amounts, for example $\mathrm{Zn}, \mathrm{Cu}, \mathrm{Fe}, \mathrm{Co}, \mathrm{Mn}$, and others. Non-essential heavy metals are metals whose benefits are unknown in the body, even if they are toxic, for example: $\mathrm{Hg}, \mathrm{Cd}, \mathrm{Pb}, \mathrm{Cr}$, and others (Widowati 2008). The presence of heavy metals in the landfill is very dangerous to the environment around the landfill because these heavy metals are toxic. Heavy metals that come from leachate have the potential to seep into the soil which will contaminate groundwater. If this heavy metal has polluted ground water, it will pollute wells around the population which are generally used by residents for their daily needs.

The results of (Nindhianingtyas 2013) stated that the lead content in the monitoring well water of the Pakusari TPA on average $0.152 \mathrm{ppm}$ with a maximum limit of $0.05 \mathrm{mg} / 1$ and an average leachate pool content of $0.141 \mathrm{ppm}$ with a maximum limit of $0.1 \mathrm{mg} / 1$. The results of research by (Moelyaningrum, A.D dan Pujiati 2015) stated that the content of cadmium $(\mathrm{Cd})$ in pond 1 was $0.029 \mathrm{ppm}$, pool 2 was 0.044 ppm, pool 3 was 0.045 with a maximum limit of $0.010 \mathrm{mg} / 1$ and content mercury $(\mathrm{Hg})$ in pool 2 was $0.013 \mathrm{ppm}$, pool 3 was $0.021 \mathrm{ppm}$ with a maximum limit of 0.001 and the monitoring wells were all contaminated with $\mathrm{Cd}$ but not $\mathrm{Hg}$. The results of (Aditama 2017) showed that the lead content in the dug wells of residents around the Pakusari TPA was $26.9 \%$ exceeding the quality standard and the results of (Qadriyah 2018) research stated that the cadmium content in the dug wells around the Pakusari TPA was $80 \%$ exceeding the environmental quality standard.

Therefore, the potential for groundwater contamination by heavy metals is very likely to occur. Therefore, this research is important to do to determine the level of heavy metal concentration in groundwater. The purpose of this study was to identify the level of heavy metal concentration $(\mathrm{Cu}, \mathrm{Pb}, \mathrm{Hg})$ in the well water around the Batu Bola landfill. The expected benefit from this research is an effort to control groundwater pollution caused by the Batu Bola landfill and as a material for recommendations and considerations for the local government, regarding the feasibility of the Batu Bola landfill location in Batu Bola Village.

\section{RESEARCH METHODS 2.1. Time and Location of Research}

This research was conducted for 3 months starting from February-April 2020. The research sample was taken in Batu Bola Village, Padangsidimpuan Selatan District, Padangsidimpuan City. Testing of heavy metal levels $(\mathrm{Pb}, \mathrm{Cu}$ and $\mathrm{Hg}$ ) was carried out at the Medan Industrial Research and Standardization Testing Laboratory (BARISTAND).

\subsection{Tools and Materials}

The tools used in this study were the atomic absorption spectrophotometer (AAS), $300 \mathrm{~mL}$ white plastic bottles, $10 \mathrm{ml}$ and $50 \mathrm{~mL}$ volumetric pipettes, volumetric flasks, Erlenmeyers, vacuum devices, 0.45 $\mu \mathrm{m}$ membrane filters, analytical scales. The materials in this study were dug well water, distilled water,

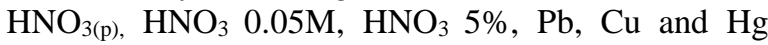
metals, aethylene gas. (SNI 6989.8-2009; SNI 6989.62009 and SNI 06-2462-1991).

\subsection{Research Procedure}

\subsubsection{Sampling Technique}

The sampling technique for the well water test was purposive sampling by considering the distance between the well and the TPA. The test samples were taken from 2 points with a distance of 100 meters and 300 meters from the landfill. Water samples were taken by varying the depth of the well, namely the bottom, middle and top, so that the analyzed water sample is expected to represent the water body. Water samples were taken $300 \mathrm{ml}$ with a white plastic bottle. Before being taken to the laboratory, water samples were preserved by adding concentrated $\mathrm{HNO}_{3}$ to $\mathrm{pH}<2$.

\subsubsection{Analysis of Metal Content in Samples with AAS}

The determination of $\mathrm{Pb}, \mathrm{Cu}$ and $\mathrm{Hg}$ metal content in the sample was carried out according to the SNI 6989.8-2009 procedure; SNI 6989.6-2009 and SNI 062462-1991. 50ml of sample was put into $100 \mathrm{ml}$ Erlenmeyer, added $5 \mathrm{ml}$ of concentrated $\mathrm{HNO}_{3}$ then covered with a funnel. It is heated slowly until the remaining volume is $15 \mathrm{ml}-20 \mathrm{ml}$, if the digestion is not complete (not clear) then add another $5 \mathrm{ml}$ of concentrated $\mathrm{HNO}_{3}$ then cover and heat again (not boiling) until all the metal dissolves. $\mathrm{Pb}, \mathrm{Cu}$ and $\mathrm{Hg}$ levels were tested by testing the test samples one by one into the AAS device with a wavelength of 283.3 $\mathrm{nm}$. Furthermore, the metal absorption of $\mathrm{Pb}, \mathrm{Cu}$ and $\mathrm{Hg}$ was carried out. 


\subsubsection{Data Analysis}

Measurement of heavy metal levels of $\mathrm{Pb}, \mathrm{Cu}$ and $\mathrm{Hg}$ in well water obtained from the test results is then compared with the standard well water quality standards set by the Government, namely through Permenkes No. 492 of 2010 concerning Drinking Water Quality Requirements and Government

Based on the measurement results, the concentration of lead, copper and merukiri in the dug well water of the respondents in this study did not

\begin{tabular}{lccc} 
Table 1. Measurement Results of Heavy Metals in Well Water 1 and 2 \\
\hline Parameter & Results & Unit & Test Results \\
& $<0,0004$ & $\mathrm{mg} / \mathrm{L}$ & SNI 6989.8-2009 \\
\hline Mercury & $<0,003$ & $\mathrm{mg} / \mathrm{L}$ & SNI 6989.8-2009 \\
Lead & & & \\
& $<0,006$ & $\mathrm{mg} / \mathrm{L}$ & SNI 06-2462-1991 \\
Copper & & &
\end{tabular}

Environmental lead is a bound particle with low mobility and bioavailability. Lead is not an essential substance for living things. Lead can cause biological effects that vary with dose and duration of exposure. The impact can only be in the form of enzyme inhibition that causes morphological changes to the most severe in the form of death. Children are more susceptible to the adverse effects of lead than adults. (Nguyen BT, Nguyen VN, Truong HTT, Do DD, Nguyen TX, Nguyen DTP 2020). The effects that can occur due to lead exposure are anemia, increased blood pressure, kidney damage, decreased IQ in children, decreased sperm motility (movement) and pregnancy disorders. However, lead has not been shown to cause cancer (Organization 1995). The lead content in surface water and groundwater depends on the source of the pollutant. Lead found from water can be sourced from waste materials for batteries, ammunition, metal products (sheet metal, solder and pipes), medical equipment (radiation protection and surgical instruments), paints, ceramics, scientific / practical equipment. (Uwah EI, Nwoke IB, Inam EJ, Udosen IE 2020).
Regulation Number 82 of 2001 concerning Management of Water Quality and Class I Water Pollution Control.

\section{RESULTS AND DISCUSSION}

\subsection{Lead, Copper and Mercury in Dug Well Water}

meet the quality standards of Permenkes 492/ Menkes Per /IV/2010 and Government Regulation Number 82 of 2001. real, as shown in table 1 .

Biologically and chemically mercury can be transformed into methyl mercury and dimethylmercury. Methyl mercury has bioaccumulative properties while dimethyl mercury is volatile and can move to very far. Mercury and its compounds are heavy metals that are highly toxic to humans. Mercury's toxicity depends on the type of mercury. In general, organic mercury is more dangerous than the inorganic form. Mercury can cause central nervous system disorders (such as mental retardation, deafness, blindness, speech problems) and kidney damage. (Ashar, T, Santi D.N dan Naria 2013).

The presence of the element copper $(\mathrm{Cu})$ in nature can be found in the form of free metals, but is more commonly found in compounds. $\mathrm{Cu}$ is included in the essential metal group, where in low levels it is needed by organisms as a coenzyme in the body's metabolic processes, its toxicity only appears in high levels. According to (Palar 2004) at a concentration of $0.01 \mathrm{ppm}$ phytoplankton will die because $\mathrm{Cu}$ inhibits enzyme activity in phytoplankton cell division. $\mathrm{Cu}$ concentrations in the range of 2,5-3,0 $\mathrm{ppm}$ in water bodies will kill fish. The waste management system at the Batu Bola landfill can potentially pollute groundwater because the garbage dumped in the TPA will rot along with rainwater and will produce leachate. Copper $(\mathrm{Cu})$ content in waste and leachate can easily spread following the movement of water flow in the soil. 
Table 2. Water Quality Standards Class I

\begin{tabular}{lcc}
\hline \multirow{2}{*}{ Parameter } & \multicolumn{2}{c}{ Highest Levels } \\
& Value & Unit \\
\hline Mercury & 0,001 & $\mathrm{mg} / \mathrm{L}$ \\
Lead & 0,03 & $\mathrm{mg} / \mathrm{L}$ \\
Copper & 0,02 & $\mathrm{mg} / \mathrm{L}$ \\
\hline
\end{tabular}

Source: Government Regulation Number 82 Year 2001

The concentration of $\mathrm{Pb}$ in well water 1 and 2 from the test results is $<0.003 \mathrm{mg} / \mathrm{L}$, this value is still below the threshold set by the government, namely 0.03 $\mathrm{mg} / \mathrm{L}$ and $0.01 \mathrm{mg} / \mathrm{L}$. The results of measuring $\mathrm{Cu}$ metal content also showed that the $\mathrm{Cu}$ metal content was still below the established threshold, namely $<0.006 \mathrm{mg} / \mathrm{L}$, while the threshold levels were $0.02 \mathrm{mg}$ / $\mathrm{L}$ and $2 \mathrm{mg} / \mathrm{L}$. Furthermore, the results of measuring the $\mathrm{Hg}$ metal content are $<0.0004 \mathrm{mg} / \mathrm{L}$, this value is still below the threshold set by the government, namely $0.001 \mathrm{mg} / \mathrm{L}$. The threshold that becomes the reference in comparing the level of heavy metal pollution is Government Regulation Number 82 Year 2001 and Permenkes 492/Menkes/Per/IV/2010. The results showed that the condition of the well water of the residents around the Batu Bola landfill has not experienced heavy metal pollution, but if the open dumping method is still applied to the Batu Bola landfill, it will damage the surrounding environment.

\section{CONCLUSION}

Based on the research that has been done, it can be concluded that the metal content of Copper $(\mathrm{Cu})$, Tmbal $(\mathrm{Pb})$ and Mercury $(\mathrm{Hg})$ in dug 1 well water and 2 dug well water around the Batu Bola landfill if viewed from the parameters the metal content has not crossed the threshold. for drinking water purposes, in other words, it can be categorized as clean water because it does not pass the threshold levels as clean water and drinking water, where the threshold for $\mathrm{Pb}(0.03 \mathrm{mg} / \mathrm{L}$ and $0.01 \mathrm{mg} / \mathrm{L})$, for $\mathrm{Cu}$ metal $(0.02 \mathrm{mg} / \mathrm{L}$ and $2 \mathrm{mg} / \mathrm{L})$ and for $\mathrm{Hg}$ metal (0.001 mg/L).

\section{REFERENCES}

[1] Aditama, A. 2017. "Hubungan Antara Jarak Sumur, Konstruksi Sumur Dan Tinggi Muka Air Sumur Dengan Kandungan Timbal Di Sekitar TPA Pakusari." Universitas Jember.

[2] Anilkumar, A., D. Sukamaran, and S. G. T. Vincent. 2015. "Effect of Municipal Solid Waste Leachate on Ground Water Quality of Thiruvananthapuram District, Kerala, India."
Table 3. Requirements for Drinking Water Quality

\begin{tabular}{lcc}
\hline \multirow{2}{*}{ Parameter } & \multicolumn{2}{c}{ Highest Levels } \\
& Value & Unit \\
\hline Mercury & 0,001 & $\mathrm{mg} / \mathrm{L}$ \\
Lead & 0,01 & $\mathrm{mg} / \mathrm{L}$ \\
Copper & 2 & $\mathrm{mg} / \mathrm{L}$
\end{tabular}

Source: Permenkes 492 / Menkes / Per / IV / 2010

Applied Ecology and Environmental Sciences 3(5): 151-57.

[3] Ashar, T, Santi D.N dan Naria, E. 2013. "Kromium, Timbal, Dan Merkuri Dalam Air Sumur Masyarakat Di Sekitar Tempat Pembuangan Akhir Sampah.” Jurnal Kesehatan Masyarakat Nasional 7(9): 408-14.

[4] Bali, S. 2012. "Kandungan Logam Berat (Timbal, Cadmium), Amoniak, Nitrit Dalam Air Minum Isi Ulang." Universitas Riau.

[5] Harahap, FS. 2018. "Analysis of Heavy Metals Distribution in the River Town of Hamasakis"s Rod Padangsidimpuan. Eksakta.” Eksakta 19(2): 50-56.

[6] Moelyaningrum, A.D dan Pujiati, R.S. 2015. "Cadmium (Cd) and Mercury ( $\mathrm{Hg})$ in the Soil, Leachete and Ground Water at the Final Waste Disposal PakusariJember District Area." International Journal of Sciences: Basic and Applied Research 24(2): 101-8.

[7] Nasution, H.I dan Silaban, S. 2017. "Analisis Loga Berat Pb Dan Cd Dalam Air Sumur Di Sekitar Lokasi Pembuangan Sampah Akhir." Jurnal ITEKIMA 1(1): 17-24.

[8] Nguyen BT, Nguyen VN, Truong HTT, Do DD, Nguyen TX, Nguyen DTP, et al. 2020. "Assessment and Source Quantification of Heavy Metal(Loid)s in Surface Water Using Multivariate Analyses from the Saigon River, Vietnam." Environmental science and pollution research international 27(16): 19383-97.

[9] Nindhianingtyas, W.N. 2013. "Analisis Potensi Pencemaran Timbal Pb Pada Tanah, Air Lindi Dan Air Tanah (Sumur Monitoring Di TPA Pakusari Kabupaten Jember." Universitas Jember.

[10] Organization, World Health. 1995. "Environmental Health Criteria 165: Inorganic Lead." Geneva, Switzerland: International Programme on Chemical Safety (IPCS).

[11] Palar, H. 2004. Pencemaran Dan Toksikologi Logam Berat Edisi Kedua. Kedua. Jakarta: Rineka Cipta. 
[12] Qadriyah, L. 2018. "Hubungan Antara Jarak Dan Konstruksi Sumur Gali Di Sekitar TPA Pakusari Kabupaten Jember." Universitas Jember.

[13] Uwah EI, Nwoke IB, Inam EJ, Udosen IE, Udosen ED. 2020. "Human Health Risk Assessment of Heavy Metal Contamination in New Calabar River." Bulletin of environmental contamination and toxicology 105(2): 317-24.
[14] Wardi, E.S, Arel, A dan Yongki, B. 2018. "Analisa Kandungan Timbal (Pb) Dan Kromium (Cr) Air Sumur Di TPA Air Dingin Kota Padang." Scientia Junal Farmasi dan Kesehatan 8(1): 125-29.

[15] Widowati. 2008. Efek Toksik Logam. Yogyakarta: Andi Offset.y 